\title{
Work-related respiratory disorders in persons employed in Quebec cotton textile mills - 1980 to 1995
}

\author{
Raymond Bégin MD, Marc Desmeules MD, Jean-Jacques Gauthier MD, Gaston Ostiguy MD \\ Comité des Présidents, Commission de santé et sécurité au travail du Québec, \\ Québec City, Québec
}

R Bégin, M Desmeules, J-J Gauthier, G Ostiguy. Work-related respiratory disorders in persons employed in cotton textile mills in Quebec - 1980 to 1995. Can Respir J 1997;4(5):273-279. Byssinosis, a chronic lung disease of cotton mill workers, is characterized by repeated episodes of reversible airway obstruction, which can lead to permanent alterations of lung function. When this occurs in Quebec the worker must be removed from further exposure in accordance with the provincial compensation rules. The current Quebec Occupational Safety and Health Regulation has a permissible exposure limit of $500 \mu \mathrm{g} / \mathrm{m}^{3}$, resulting in a prevalence rate of byssinosis of $2 \%$ to $5 \%$ in cotton workers. In this study the incidence of new respiratory disorders in persons employed in Quebec cotton mills from 1980 to 1995 was assessed and factors that identified byssinosis cases were analyzed. Incidence of the disease was assessed on the basis of cases referred to the Commission de Santé \& Sécurité au travail du Québec (Quebec Workers' Compensation Board) from all Quebec textile plants. Analyses of age, years of employment, job description, smoking history, bronchial reactivity and lung function before and at work were used for diagnostic purposes. Incidence of new byssinosis cases from 1990 to 1995 was 2.8 cases per year per 5000 workers, slightly above the incidence from 1980 to 1989 , at 1.7 cases per year. The incidence of chronic cases was stable at 1.5 cases per year, whereas that of early cases increased from 0.3 cases per year (1980 to 1989) to 1.25 cases per year (1990 to 1995). In comparison with chronic byssinosis cases, the average time of work before symptom appearance was $17 \pm 4$ versus $32 \pm 1$ years, $\mathrm{P}<0.001$. Bronchial reactivity to methacholine $\left(\mathrm{PC}_{20}\right)$ at work was below $2 \mathrm{mg} / \mathrm{mL}$ in $100 \%$ of byssinosis cases versus $14 \%$ in subjects not diagnosed with byssinosis. Decreases in forced expiratory volume in $1 \mathrm{~s}\left(\mathrm{FEV}_{1}\right)$ at work averaged $30 \%$ in the byssinosis and $6 \%$ in the nonbyssinosis subjects; peak flow rates were not different between those with and those without byssinosis. Early byssinosis cases were from three distinct plants in different townships, and $45 \%$ of cases worked in cardroom occupations. $\mathrm{PC}_{20}$ equal to or less than $2 \mathrm{mg} / \mathrm{mL}$ at work was strongly associated with the decrease in $\mathrm{FEV}_{1}$ during a work shift. In conclusion, current cotton processing work in Quebec is associated with a significant incidence of byssinosis. $\mathrm{PC}_{20}$ of $2 \mathrm{mg} / \mathrm{mL}$ or less at work was closely associated with airflow limitation at work.

Key Words: Airway reactivity, Occupational byssinosis, Pulmonary function

\section{Maladies pulmonaires professionnelles chez les travailleurs des filatures de coton du Québec : 1980-1995}

RÉSUMÉ : La byssinose, maladie pulmonaire chronique des travailleurs du coton, est caractérisée par des épisodes répétés d'obstruction bronchique réversible, pouvant entraîner une altération permanente de la fonction pulmonaire. Au Québec, un retrait permanent de l'exposition est alors prescrit par la Loi des 
accidents du travail. La Réglementation sur la qualité de l'air en milieu de travail du Québec contient actuellement une norme d'empoussiérage de $500 \mu \mathrm{g} / \mathrm{m}^{3}$, ce qui résulte en un taux de prévalence de la byssinose de $2 \%$ à $5 \%$ parmi les travailleurs du coton. Dans la présente étude, nous avons étudié l'incidence des nouveaux cas de maladies pulmonaires chez les travailleurs du coton de 1980 à 1995 et analysé les facteurs différenciant les cas de byssinose des autres cas. L'incidence de la maladie a été évaluée sur la base des cas adressés à la Commission de santé et sécurité au travail du Québec et provenant de toutes les filatures de cette province. Les analyses prenant en considération l'âge, le nombre d'années d'emploi, les tâches, le tabagisme, la réactivité bronchique et la fonction pulmonaire de base et au travail ont été utilisées à des fins de diagnostic de la byssinose. De 1990 à 1995, l'incidence des nouveaux cas de byssinose était de 2,8 cas par an par 5000 travailleurs, incidence légèrement supérieure à celle observée de 1980 à 1989 établie à 1,7 cas par an. L'incidence des cas chroniques était stable à 1,5 cas par an tandis que le nombre de cas de byssinose précoce est passé de 0,3 cas par an (1980 à 1989) à 1,25 cas par an (1990 à 1995). Comparativement aux cas chroniques de byssinose, le temps moyen d'exposition au travail avant l'apparition des symptômes était de $17 \pm 4$ contre $32 \pm 1$ ans, $\mathrm{P}<0,001$. La réactivité bronchique à la méthacoline $\left(\mathrm{CP}_{20}\right)$ au travail était inférieure à $2 \mathrm{mg} / \mathrm{mL}$ dans $100 \%$ des cas de byssinose contre $14 \%$ chez les sujets sans diagnostic de byssinose. La chute du VEMS au travail était en moyenne de $30 \%$ chez les sujets atteints de byssinose comparativement à $6 \%$ chez les sujets non atteints de byssinose ; les débits de pointe étaient similaires dans les deux groupes. On a identifié les cas de byssinose précoce dans 3 usines distinctes dans des villes différentes et $45 \%$ des cas étaient des cardeurs. Une $\mathrm{CP}_{20}$ égale ou inférieure à $2 \mathrm{mg} / \mathrm{ml}$ au travail était fortement associée à une diminution du VEMS pendant le travail. En conclusion, au Québec, le travail dans les filatures de coton est associé à une incidence non négligeable des cas de byssinose. La $\left(\mathrm{CP}_{20}\right)$ de $2 \mathrm{mg} / \mathrm{mL}$ ou moins au travail est étroitement associée à une obstruction du débit aérien.
B yssinosis, a disease of cotton workers, embraces a spectrum of respiratory symptoms including acute dyspnea, cough usually producing clear sputum and chest tightness occurring on one or more days of the work week in association with cotton dust exposure. Classically, the symptoms are worst early in the working week, particularly after a period of absence from work, and, in the early stages of byssinosis, are not associated with permanent loss of lung function. As byssinosis progresses, the temporal variation in symptoms becomes less distinctive, and permanent loss of lung function is observed. Asthmatics who develop respiratory symptoms immediately after contact with cotton mill work usually stop working and should not be considered as suffering from byssinosis (1).

It has become clear that airway hyper-reactivity is very prevalent in byssinosis; symptomatic cotton workers (2) who show a significant reduction in forced expiratory volume in $1 \mathrm{~s}\left(\mathrm{FEV}_{1}\right)$ at work fulfil the objective criteria of work related disease. A change in $\mathrm{FEV}_{1}$ during a shift predicts an annual change in $\mathrm{FEV}_{1}(3,4)$. In addition, the cotton dust permissible exposure level (PEL) has been lowered, and the traditional five-day, $8 \mathrm{~h}$ shift work schedule has been changed to a three-day, $12 \mathrm{~h}$ shift schedule for many workers in recent years. These factors may have changed the classical temporal variability in symptoms in symptomatic workers with increased airway reactivity $(2,5)$.

Clearly, a significant objective deterioration of lung function (greater than $10 \%$ reduction in $\mathrm{FEV}_{1}$ at work) remains the cornerstone of the clinical diagnosis of byssinosis in workers with sufficient industrial exposure (usually more than five years) and frequent respiratory symptoms at work, consistent with the World Health Organization (WHO) 1983 classification (6). The level at which symptoms warrant a diagnosis of byssinosis, followed by removal from work in the textile industry, remains uncertain and is the subject of further investigation.

Given the above considerations and a recent increase (11 in the past two years) in symptomatic cotton workers referred to the Commission de Santé \& Sécurité au travail du Québec
(Quebec Workers' Compensation Board) (CSST) for evaluation, we reviewed the incidence of cases from 1980 to 1995, and the prevalence of symptoms, airway reactivity, workrelated loss of $\mathrm{FEV}_{1}$, permanent loss of lung function and job description of the referred cases, and compared them with a group of symptomatic cotton workers who were not diagnosed with byssinosis. We also analyzed the characteristics of early byssinosis, defined by repeated episodes of moderate and reversible airway obstruction on exposure to cotton dust (6), as shown by a greater than $10 \%$ reduction in $\mathrm{FEV}_{1}$ during a shift, and analyzed the incidence of such cases over time. We studied the prevalence of classical symptoms of early byssinosis (3) and compared the workers with early signs of byssinosis with cases of permanent loss of lung function. Finally, we examined the association between enhanced airway reactivity at work and work-related reduction in $\mathrm{FEV}_{1}$.

\section{PATIENTS AND METHODS}

Quebec cotton textile workers: The Quebec cotton mill industry has a 150 -year history, and employs about $50 \%$ of cotton workers in Canada. Five plants employ about 1000 workers each, for a total estimated workforce of 5000 workers, mean $4472 \pm 210$ for the past 15 years (unpublished data).

In the present study, a history and spirometry were not taken for all plant workers. However, each plant has a medical office with attending physicians and nurses, to whom workers can report respiratory symptoms and other ailments for referral to CSST. Private physicians may send workers for CSST evaluation, upon the request of workers. Thus, workers who are sufficiently concerned by work-related symptoms are referred to the CSST Occupational Lung Disease Panels.

Referral to CSST constitutes the basis of assessment of disease incidence in this population. It is recognized that the distinction between a 'normal' airway reaction to cotton exposure, as seen in many cotton workers, and byssinosis is not always easy to establish. The presence of sufficient symptoms to require referral to CSST seems to be a reasonable indicator of sickness, which, in conjunction with work-related 


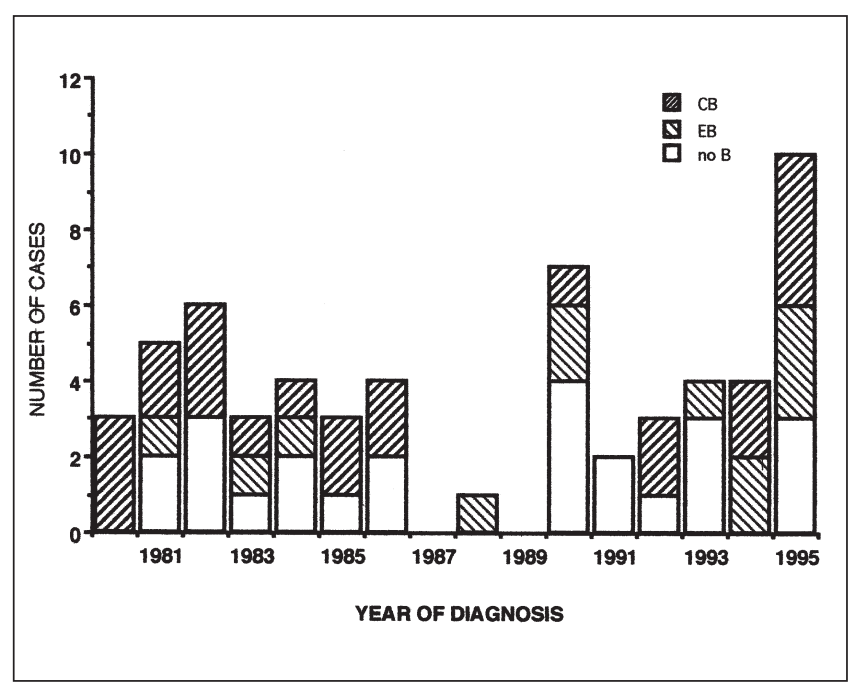

Figure 1) Incidence of symptomatic cases referred for possible byssinosis and the outcome diagnosis, into no byssinosis (NB), early byssinosis $(E B)$ or chronic byssinosis $(C B)$ groups

spirometric data, should help to separate 'nondisease' airway response to cotton dust (ie, insufficient to cause troublesome symptoms) from byssinosis.

Diagnosis of byssinosis: Diagnosis of byssinosis was made by consensus among three chest physicians who were members of the local Occupational Lung Disease Panel of the CSST and was approved by the Comité des Présidents of CSST, a legally constituted group consisting of the presidents of the four local Occupational Lung Disease Panels, which advises on all cases of occupational lung diseases.

The diagnosis was made on the best available evidence for each individual case, based on symptoms, occupational exposure history, pulmonary function tests and on-site documentation of worsening lung function upon exposure during one or more shifts (greater than $10 \%$ reduction in $\mathrm{FEV}_{1}$ ). Some workers also had personal measurements of serial peak flow rates (PFR).

In most cases, there was a four-week period of spirometry measurements, four times daily (before work, $3 \mathrm{~h}$ and $6 \mathrm{~h}$ later, and at the end of the shift); in the first two weeks the worker was off work (baseline), and in the last two weeks was on the worksite and doing his or her usual duties (at work). Measurements of methacoline response $\left(\mathrm{PC}_{20}\right)$ were made at the beginning and end of each week. Two cases were documented on the basis of laboratory cotton dust exposure only.

Subjects who were not considered to have byssinosis (NB) had on-site spirometric measurements of less than $10 \%$ reduction in $\mathrm{FEV}_{1}$ in at work measurements. Subjects recognized as having byssinosis had respiratory symptoms consistent with the byssinosis syndrome (WHO 1983 classification) (3) and on-site spirometric measurements of greater than $10 \%$ reduction in $\mathrm{FEV}_{1}$ during at least one shift, in all but two cases documented by a combination of serial PFR, spirometry and $\mathrm{PC}_{20}$ measurement made in the nearest hospital. Byssinosis cases were categorized as early (EB) or chronic byssinosis (CB). EB was defined as repeated episodes of
TABLE 1

Personal characteristics of workers referred to the Commission de Santé \& Sécurité au travail du Québec 1980 to 1995

\begin{tabular}{lccc}
\hline & $\begin{array}{c}\text { No } \\
\text { byssinosis } \\
(\mathbf{n}=\mathbf{2 2})\end{array}$ & $\begin{array}{c}\text { Early } \\
\text { byssinosis } \\
(\mathbf{n}=\mathbf{1 1})\end{array}$ & $\begin{array}{c}\text { Chronic } \\
\text { byssinosis } \\
(\mathbf{n}=\mathbf{2 3})\end{array}$ \\
\hline $\begin{array}{l}\text { Age (years) } \\
\begin{array}{c}\text { Work history } \\
\text { (years worked) }\end{array}\end{array}$ & $51 \pm 2$ & $39 \pm 3^{*}$ & $59 \pm 1$ \\
$\begin{array}{c}\text { Smoking history } \\
\text { (pack-years) }\end{array}$ & $26 \pm 3$ & $17 \pm 4^{*}$ & $32 \pm 1$ \\
$\begin{array}{c}\text { Current smoker } \\
\text { Ex- or nonsmoker }\end{array}$ & $21 \pm 5$ & $14 \pm 3$ & $31 \pm 2$ \\
\hline
\end{tabular}

Values expressed as \pm SEM. Ex-smokers Participants who had stopped smoking at least one year before assessment. There was no significant difference in smoking status distribution among groups by $\chi^{2}$. ${ }^{*} P<0.05$ versus chronic byssinosis only by ANOVA with posthoc Scheffé's test

symptomatic, moderate and reversible airway obstruction on exposure to cotton dust $(1,2)$, with a greater than $10 \%$ reduction in $\mathrm{FEV}_{1}$ at work, in the absence of permanent changes in lung function, excluding airway hyper-reactivity. CB was defined as repeated episodes of symptomatic, moderate and reversible airway obstruction on exposure to cotton dust $(1,2)$, with a greater than $10 \%$ reduction in $\mathrm{FEV}_{1}$ at work, and associated with permanent changes in lung function consistent with those reported in byssinosis. Sporadic and random changes in $\mathrm{FEV}_{1}$ at work were not considered to indicate byssinosis.

Subjects: Fifty-six cotton workers had sufficient workrelated respiratory symptoms to warrant referral to CSST respiratory panels for evaluation from 1980 to 1995 . Twentytwo were not considered to have byssinosis, in the absence of classic symptomatology and/or the absence of a significant fall of $\mathrm{FEV}_{1}$ at work. Eleven were categorized as EB and 23 as CB. Pulmonary function tests: Lung volumes, flow-volume curves, diffusion capacity and gas exchange at rest were measured according to standard methods as previously described (8). Functional residual capacity was determined by helium rebreathing, from which residual volume was derived. Diffusion capacity was measured by the single breath carbon monoxide method. Predicted values for lung volumes were those of Goldman and Becklake (9), diffusion capacity those of Miller et al (10) and spirometry those of Knudson et al (11). Bronchial reactivity was determined by the methacholine bronchoprovocation challenge of Cockcroft et al (12). Reactivity was considered to be increased when the provocation concentration of $\mathrm{PC}_{20}$ was equal to or less than $8 \mathrm{mg} / \mathrm{mL}$ (13). All spirometric measurements were carried out by trained technicians or nurses on equipment meeting American Thoracic Society standards $(14,15)$.

Cotton dust level sampling: Individual measurements of cotton dust exposure on an average shift were not obtained, and all cotton dust samples were work area measurements available through the companies' Health \& Safety Procedures Records, using a vertical elutriator cotton dust sampler to measure cotton dust gravimetrically in $\mathrm{mg} / \mathrm{m}^{3}$ air. Most 
TABLE 2

Lung function tests of workers referred to the Commission de Santé \& Sécurité au travail du Québec 1980 to 1995

\begin{tabular}{lccc}
\hline & No byssinosis $(\mathbf{n}=\mathbf{2 2})$ & Early byssinosis $(\mathbf{n}=\mathbf{1 1})$ & Chronic byssinosis $(\mathbf{n}=\mathbf{2 3})$ \\
\hline Total lung capacity (percentage predicted) & $110 \pm 3$ & $112 \pm 4$ & $114 \pm 3$ \\
Vital capacity (percentage predicted) & $103 \pm 4$ & $109 \pm 5^{*}$ & $90 \pm 4$ \\
Residual volume (percentage predicted) & $120 \pm 7$ & $118 \pm 10^{*}$ & $160 \pm 9^{\dagger}$ \\
Diffusion capacity (percentage predicted) & $105 \pm 6$ & $94 \pm 6$ & $94 \pm 3$ \\
FEV (percentage predicted) & $78 \pm 6$ & $99 \pm 4^{*}$ & $59 \pm 2^{\dagger}$ \\
Maximum midexpiratory flow rate & $57 \pm 8$ & $75 \pm 6^{*}$ & $28 \pm 2^{\dagger}$ \\
$\quad$ percentage predicted) & & & \\
$\mathrm{PC}_{20}(\mathrm{mg} / \mathrm{mL})$ & $8.7 \pm 3.9$ & $6.9 \pm 1.9$ & $2.7 \pm 1.1$ \\
\hline
\end{tabular}

Values expressed as \pm SEM. ${ }^{*} P<0.05$ versus chronic byssinosis; ${ }^{\dagger} P<0.05$ versus no byssinosis. FEV $V_{1}$ Forced expired volume in $1 \mathrm{~s}$; $P C_{20}$ Value of the provocation concentration of methacholine causing a $20 \%$ fall in FEV ${ }_{1} . P C_{20}$ was the value obtained at time of initial assessment

TABLE 3

Work-related symptoms (World Health Organization 1983 classification)

\begin{tabular}{|c|c|c|c|}
\hline Symptom Class & No byssinosis $(n=22)$ & Early byssinosis $(n=11)$ & Chronic byssinosis $(n=23)$ \\
\hline No symptoms $(0)$ & 9 & 0 & 0 \\
\hline $\begin{array}{l}\text { Chest tightness and/or shortness of breath on most first } \\
\text { days back at work (B1) }\end{array}$ & 14 & 11 & 19 \\
\hline $\begin{array}{l}\text { Chest tightness and/or shortness of breath on the first } \\
\text { and other days of the working week (B2) }\end{array}$ & 3 & 10 & 15 \\
\hline Cough associated with dust exposure (RTI 1) & 7 & 9 & 11 \\
\hline $\begin{array}{l}\text { Persistent phlegm (on most days during three months of } \\
\text { the year) initiated or exacerbated by dust exposure } \\
\text { (RTI 2) }\end{array}$ & 2 & 3 & 5 \\
\hline $\begin{array}{l}\text { Persistent phlegm initiated or made worst by dust } \\
\text { exposure either with exacerbation of chest illness or } \\
\text { persisting for two years or more (RTI 3) }\end{array}$ & 0 & 0 & 0 \\
\hline Wheezing & 6 & 11 & 13 \\
\hline
\end{tabular}

Statistical analyses by $\chi^{2}$ revealed significant differences at $P<0.05$ between groups for all symptom classes except for $R T I 3$

measurements were usually between 0.10 and $0.5 \mathrm{mg} / \mathrm{m}^{3}$ air. PEL in Quebec is less than $0.5 \mathrm{mg} / \mathrm{m}^{3}$ air and was less than that in more than $95 \%$ of occasions and areas. Endotoxin levels were not measured.

Statistical analyses: All results were expressed as mean \pm SEM, expressed in terms of percentage predicted except for $\mathrm{PC}_{20}$, which was expressed in $\mathrm{mg} / \mathrm{mL}$. Data were tested by ANOVA with post hoc Scheffé's test to compare group data. To study the association between variables in the study, multiple variate analyses of variance (MANOVA) and logistic regression analyses for byssinosis predictors (16-18) were used. $\mathrm{P}<0.05$ was considered significant.

\section{RESULTS}

Incidence of byssinosis: The incidence of byssinosis in the cotton textile worker population from 1980 to 1995 is presented in Figure 1. With a total of 34 new cases of byssinosis (11 EB and $23 \mathrm{CB}$ ), the incidence of cases per year was $2.1 \pm 1$. From 1980 to 1989 , there were 17 cases (three EB and $14 \mathrm{CB}$ ), giving an incidence of $1.7 \pm 1$ byssinosis cases per year. From 1990 to 1995, there were 17 new cases of byssinosis (eight $\mathrm{EB}$ and nine $\mathrm{CB}$ ) reported, an incidence of $2.8 \pm 1$ cases per year $(\mathrm{P}>0.05$, not significant compared with 1980 to 1989 results). However, the number of EB cases in the last six years was higher than previously seen (eight cases or 1.25 per year from 1990 to 1995 versus three cases or 0.3 case per year from 1980 to 1989). The incidence of CB was stable nine cases or 1.5 per year from 1990 to 1995 versus 14 cases or 1.4 per year from 1980 to 1989. There was no significant change in the compensation legislation for byssinosis from 1980 to 1995.

Personal characteristics: Age at time of referral, years worked as an index of dust exposure, smoking history expressed in pack-years, and current smoking status for the subject groups are presented in Table 1. The EB group was younger, and consequently, years worked and pack-years were lower. The average number of cigarettes smoked per day did not differ among the groups.

Lung function: Lung volumes, diffusion capacity, baseline expiratory flow rates and airway reactivity test results are presented in Table 2 . The NB group was a mixture of normal subjects and subjects with chronic airflow limitation, explaining the values for airway reactivity in the group compared with the general population. All subjects in the EB group had normal baseline lung function. In the CB group, all subjects had chronic airflow limitation; diffusion capacity was normal. The baseline $\mathrm{PC}_{20}$ was abnormal (less than $8 \mathrm{mg} / \mathrm{mL}$ ) in $67 \%$ of the NB group, $60 \%$ of the EB group and $90 \%$ of the CB group.

Job description: Because of the diversity of operations in 
TABLE 4

Work-related lung function changes (World Health Organization 1983 classification)

\begin{tabular}{|c|c|c|c|}
\hline & No byssinosis $(n=22)$ & Early byssinosis $(n=11)$ & Chronic byssinosis $(n=23)$ \\
\hline \multicolumn{4}{|l|}{ Acute fall in $\mathrm{FEV}_{1}$} \\
\hline Not done & 8 & 1 & 9 \\
\hline Less than $5 \%$ & 9 & 0 & 0 \\
\hline $5 \%$ to $10 \%$ & 2 & 0 & 0 \\
\hline $10 \%$ to $20 \%$ & 3 & 4 & 3 \\
\hline More than $20 \%$ & 3 & 6 & 11 \\
\hline \multicolumn{4}{|c|}{ Chronic reduction in $\mathrm{FEV}_{1}$ (percentage predicted) } \\
\hline More than $80 \%$ & 13 & 11 & 1 \\
\hline $60 \%$ to $79 \%$ & 1 & 0 & 7 \\
\hline Less than $60 \%$ & 8 & 0 & 15 \\
\hline \multicolumn{4}{|l|}{$\mathrm{PC}_{20}$} \\
\hline $\mathrm{PC}_{20}$ baseline $( \pm \mathrm{SEM})$ & $8.7 \pm 3.9$ & $6.9 \pm 1.9$ & $2.7 \pm 1.1$ \\
\hline $\mathrm{PC}_{20}$ at work & $4.1 \pm 1.4$ & $1.2 \pm 0.2^{*}$ & $1.0 \pm 0.6$ \\
\hline
\end{tabular}

Statistical analyses revealed significant differences at $P<0.05$ (by $\left.\chi^{2}\right)$ between groups for acute and chronic changes in forced expired volume in $1 \mathrm{~s}\left(F E V_{1}\right)$. ${ }^{*} P<0.05$ versus no byssinosis, by ANOVA with posthoc Scheffé's test

the five cotton plants, the type of work was divided into cardroom work and other site work. Five of 11 (45\%) EB cases were cardroom workers; whereas 10 of 23 (43\%) of CB and six of 25 (24\%) of the NB group were cardroom workers, $\chi^{2}=4.5, \mathrm{P}<0.02$ for the risk of byssinosis in cardroom work versus other work.

Symptoms: Work-related symptoms, using the WHO 1983 classification, are presented in Table 3. Chest tightness or dyspnea at work were present in the majority of byssinosis cases (EB or $\mathrm{CB}$ ); these symptoms were present in a lower proportion of NB subjects. Cough and wheezing were also common complaints in the byssinosis groups.

Work-related lung function changes: Variations in lung function measured by spirometry during days at work are presented in Table 4, tabulated by WHO 1983 classification. Mean changes in $\mathrm{FEV}_{1}$ were $6.5 \pm 2.7 \%$ for the NB group, $28.9 \pm 4.2 \%$ for the $\mathrm{EB}$ group and $30.7 \pm 2.9 \%$ for the $\mathrm{CB}$ group $(\mathrm{P}<0.05$ for $\mathrm{NB}$ versus $\mathrm{EB}$ or $\mathrm{CB})$. PFR at work were also measured in half of the cases. Mean change in PFRs during a shift was $14.7 \pm 5.5 \%$ for the NB group, $31.6 \pm 6.3 \%$ for the EB group and $28.3 \pm 6.2 \%$ for the $\mathrm{CB}$ group ( $\mathrm{P}>0.05$ in all comparisons).

During the two weeks at work, airway reactivity increased in all groups, with the level of reactivity in the EB group comparable with that of the $\mathrm{CB}$ group. The reduction in $\mathrm{PC}_{20}$ was largest in the $\mathrm{EB}$ group; $\mathrm{PC}_{20}$ at work was abnormal in $83 \%$ of the NB group, $100 \%$ of the EB group and $100 \%$ of the $\mathrm{CB}$ group. $\mathrm{PC}_{20}$ was less than $2 \mathrm{mg} / \mathrm{mL}$ in $14 \%$ of the $\mathrm{NB}$ group, and $100 \%$ in both the $\mathrm{EB}$ and $\mathrm{CB}$ groups $(\mathrm{P}<0.05$ for $\mathrm{NB}$ versus $\mathrm{EB}$ or $\mathrm{CB}$ ).

Change in $\mathbf{F E V}_{1}$ at work: Age, smoking history, years worked, diffusion capacity, baseline $\mathrm{FEV}_{1}$, baseline $\mathrm{PC}_{20}$ and $\mathrm{PC}_{20}$ at work were recorded, and a significant association between the change in $\mathrm{FEV}_{1}$ at work and $\mathrm{PC}_{20}$ at work $(\mathrm{r}=0.57$, $\mathrm{P}=0.02$ ) (Figure 2) was found. Thus, the workers who had a low $\mathrm{PC}_{20}$ at work had a greater decline in $\mathrm{FEV}_{1}$ during a shift. Baseline $\mathrm{PC}_{20}$ and change in $\mathrm{PC}_{20}$ were not significantly associated with the change in $\mathrm{FEV}_{1}$ at work.

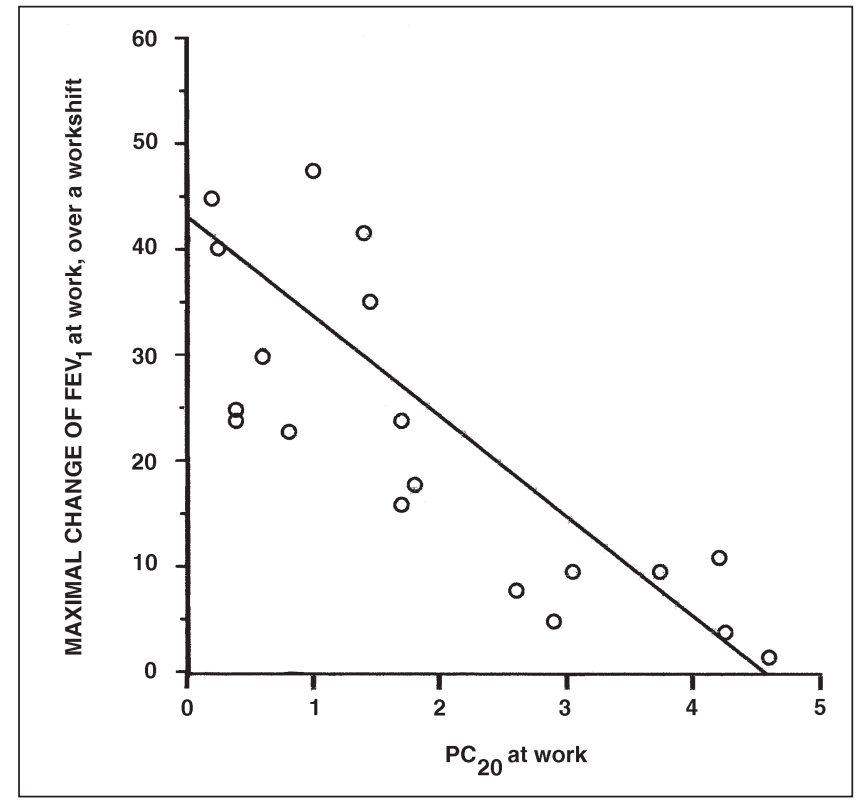

Figure 2) Linear regression of change in forced expired volume in $1 \mathrm{~s}\left(F E V_{1}\right)$ versus the provocation concentration of methacholine $\left(P C_{20}\right)$ causing a $20 \%$ fall in $F E V_{1}(r=0.57, P=0.02)$. Alternative regressions did not increase the correlation coefficient

Baseline pulmonary function: Smoking history and workyears were evaluated as predictors of baseline $\mathrm{FEV}_{1}$, maximum midexpiratory flow rate (MMEF) and diffusion capacity. Baseline $\mathrm{FEV}_{1}$ was associated significantly only with years worked $(\mathrm{P}=0.001), \mathrm{MMEF}$ with both smoking history and years worked $(\mathrm{P}<0.05)$ and diffusion capacity only with smoking history $(\mathrm{P}=0.05)$.

\section{DISCUSSION}

The incidence of byssinosis in the Quebec cotton textile workers is relatively low, two to three cases per 5000 workers per year. Over a normal work life of 35 years this incidence rate would yield an estimated prevalence of $0.014 \%$ to $0.021 \%$, at the lower level estimated by Merchant et al (19), 
based on the dose-response relationships between gravimetric dust levels and byssinosis prevalence. The values are well below the observed prevalence and incidence values reported in the 1950s in European (20) and North American plants (21) and the current values in developing countries (22). The present study may underestimate the true prevalence of byssinosis because it was not a cross-sectional survey of the entire workforce. In contrast to the diagnosis of byssinosis on the basis of symptoms consistent with the Schilling classification (21), this study was based on work-related symptoms sufficient to warrant medical consultation and on the loss of lung function upon exposure to cotton dust in the workplace. As such, it may underestimate the incidence of the disease as defined in epidemiological studies based on the Schilling classification (1). Nonetheless, this study of the incidence of clinically symptomatic byssinosis is of interest, and pertinent to the workers and employers in the textile industry. The results are directly relevant to the cost of insurance coverage through CSST or related insurer services.

Of the referred symptomatic workers, $61 \%$ were diagnosed as having byssinosis, an acceptance level within the range of other workers evaluated at CSST for other possible occupational airway diseases, such as asthma, reactive airway syndrome or other conditions associated with chronic airflow obstruction (unpublished data).

The clinical diagnosis of byssinosis is the subject of considerable debate $(1,23-27)$, and we used a consensus of opinions from three chest specialists who based the diagnosis on WHO classification of respiratory disorders arising from exposure to vegetable dusts causing byssinosis (2). Our subjects were recognized as having byssinosis when they had symptoms consistent with the disease, sufficient cotton dust exposure and significant loss of lung function at work. The recognition of byssinosis 'at the level of sickness' has the advantage of recognizing workers with undisputed symptoms and functional changes associated with their work in a cotton textile mill. Workers are subject to work retirement, or at least a revision of work assignment ensuring low cotton dust exposure, if permanent loss of lung function is present. Our recognition of byssinosis was more restrictive than the more often used classification at the symptoms level $(2,20,27)$ and, thus, does not permit a direct comparison of our data with such epidemiological studies. Given these limitations, our study nonetheless established that at the current PEL of less than $500 \mu \mathrm{g}$ cotton dust $/ \mathrm{m}^{3}$ workplace air, the incidence of byssinosis (sickness) is low but still present in the cotton textile workers' population. Further lowering of cotton dust exposure levels should therefore be encouraged, and the regulations of the Occupational Health and Safety Administration (OHSA) specific to cotton dust (28) should be implemented.

The observation of an increasing incidence of early byssinosis cases spurred on this work. The incidence of such cases from 1990 to 1995 was four times the level from 1980 to 1989; only further observations of the workforce will reveal whether this is a transient or significant trend. The apparent increase may merely be due to the near absence of such EB cases in the preceding five years. EB cases were not known asthmatics nor atopic by history; prior work of Fishwick et al (2) has shown that the prevalence of atopy is no higher in such cases than in other cotton workers. EB cases had all worked more than five years in the mills and were sufficiently symptomatic to seek medical help: their baseline lung function was normal, and $60 \%$ had baseline bronchial hyperreactivity. However, characteristically bronchial reactivity at work was increased, with $\mathrm{PC}_{20}$ being less than $2 \mathrm{mg} / \mathrm{mL}$ in $100 \%$ of cases, documenting work-related enhanced lability of their airways. EB cases in this study have similarities to some of the 'nonbyssinosis symptomatics' of Fishwick et al (2) with respect to airway reactivity, age and years worked in cotton mills. In the present study, the EB group contrasted with the NB group in their symptoms, airway reactivity and significant loss of lung function at work. They also differed from the CB group by a lack of permanent change in baseline lung function but shared a loss of lung function at work and low $\mathrm{PC}_{20}$ at work.

Considering the factors predictive of the development of work-related airway disease and loss of lung function, previous investigators have hypothesized that asymptomatic individuals with airway hyper-reactivity, when exposed to organic dusts, may increase their airway reactivity, become symptomatic and have significant loss of lung function at work (2-5,28-31). In the present study, CB subjects had increased airway reactivity when not exposed to cotton for two weeks, and decreased $\mathrm{FEV}_{1}$ on further exposure to cotton dust, in agreement with the observation of Fishwick et al (2). EB subjects had higher $\mathrm{PC}_{20}$ of cotton exposure, but at work their airway reactivity increased to the range of the $\mathrm{CB}$

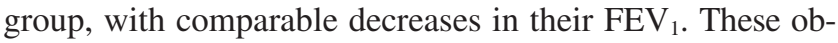
servations are consistent with the so-called 'Dutch hypothesis', whereby exposure increases bronchial reactivity, which allows the ensuing development of symptoms and loss of function. Indeed, the best predictors for the diagnosis of byssinosis (EB or $\mathrm{CB}$ ) were symptoms of chest tightness and/or shortness of breath on the first and other days of the working week (Table 3), decrease of $\mathrm{FEV}_{1}$ at work and $\mathrm{PC}_{20}$ at work of less than $2 \mathrm{mg} / \mathrm{mL}$. PFRs did not differentiate byssinosis from $\mathrm{NB}$, and their diagnostic use should be discouraged.

When considering the question of a possible relationship between the chronic airflow limitation of byssinosis and smoking habits, we found that only work exposure was significantly associated with $\mathrm{FEV}_{1}$ decline; whereas smoking was associated with decline in MMEF (reflecting small airway disease) and loss of diffusion capacity (suggestive of emphysema). These observations are consistent with current knowledge regarding the effects of smoking on working populations, and with the expected $10 \%$ to $15 \%$ prevalence of decreased $\mathrm{FEV}_{1}$ in middle-aged, blue collar workers who smoke (32-35).

In conclusion, this study established that, with a PEL of $500 \mu \mathrm{g}$ cotton dust $/ \mathrm{m}^{3}$ work place air, the incidence of byssinosis sufficient to cause symptoms ('sickness') was low but still present in the Quebec cotton textile population and that a $\mathrm{PC}_{20}$ of $2 \mathrm{mg} / \mathrm{mL}$ or less at work in cotton textile workers was closely associated with airflow limitation at work. 
ACKNOWLEDGEMENT: Supported by MRC Canada (Grant MA-9956).

\section{REFERENCES}

1. Castellan RM. Cotton dust. In: Harber P, Schenker MB, Balmes JR, eds. Occupational and Environmental Respiratory Disease. Section VI. Agents Causing Airway Disease. St Louis: Mosby, 1996:401-18.

2. Fishwick D, Fletcher AM, Pickering AC, Niven RMcL, Faragher EB. Lung function, bronchial reactivity, atopic status, and dust exposure in Lancashire cotton mill operatives. Am Rev Respir Dis 1992; 145:1103-8

3. Christiani DC, Ye TT, Wegman DH, Eisen EA, Dai HL, Lu PL. Pulmonary function among cotton textile workers. A study of variability in symptoms reporting, across-shift drop in $\mathrm{FEV}_{1}$, and longitudinal change. Chest 1994;105:1713-21.

4. Glindmeyer HW, Lefante JJ, Jones RN, Rancho RJ, Weill H. Cotton dust and across-shift change in $\mathrm{FEV}_{1}$ as predictors of annual change in FEV 1 . Am J Respir Crit Care Med 1994;149:584-90.

5. Fishwick D, Fletcher AM, Pickering CA, McL Niven R, Faragher EB Lung function in Lancashire cotton and man made fibre spinning mill operatives. Occup Environ Med 1996:53:46-50.

6. World Health Organization (WHO) Study Group. Recommended health-based occupational exposure limits for selected vegetable dusts [WHO Technical Report Series No 684]. Geneva: WHO, 1983.

7. Bates DV, Macklem PT, Christie RV. The normal lung: physiology and methods of study. In: Bates DV, Macklem PT, Christie RV, eds. Respiratory Function in Disease. Philadelphia: WB Saunders 1989:11-94, 276-80.

8. Bégin R, Ostiguy G, Cantin A, Bergeron D. Lung function in silica exposed workers: A relationship of disease severity assessed by CT scan. Chest 1988;94:539-45.

9. Goldman HI, Becklake MR. Respiratory function tests: Normal values of median altitude and the prediction of normal adults. Am Rev Tuber 1959;79:457-65.

10. Miller A, Thornton JC, Warshaw R, Anderson H, Teirstein AS, Selikoff IJ. Single breath diffusing capacity in a representative sample of the population of Michigan, a large industrial state. Am Rev Respir Dis 1983;127:270-7.

11. Knudson RJ, Lebowitz MD, Holberg CJ, Burrows B. Changes in the normal maximal expiratory flow-volume curve with growth and aging. Am Rev Respir Dis 1983;127:725-34.

12. Cockcroft DW, Killian DN, Mellon JJA, Hargreave FE. Bronchial reactivity to inhaled histamine: A method and clinical survey. Clin Allergy 1977;7:235-43.

13. American Thoracic Society. Guidelines for the evaluation of impairment/disability in patients with asthma. Am Rev Respir Dis 1993;147:1056-61.

14. Gardner RM. ATS Statement - Snowbird workshop on standardization of spirometry. Am Rev Respir Dis 1979;119:831-8.
15. American Thoracic Society. Lung function testing: selection of reference values and interpretative strategies. Am Rev Respir Dis 1991;144:1202-18.

16. Snedecor GW, Cochran WC. Statistical Methods. Ames: Iowa State University Press, 1967.

17. Fleiss JL. Statistical Methods for Rates and Proportions, 2nd edn. New York: John Wiley \& Sons, 1981

18. Siegel S. Nonparametric Statistics. New York: McGraw-Hill, 1956:195-240.

19. Merchant JA, Lumsden JC, Kilburn KH, et al. An industrial study of the biological effects of cotton dust and cigarette smoke exposure. J Occup Med 1973;15:212-21.

20. Schilling RSF. Byssinosis in cotton and other textile workers. Lancet 1956;ii:261-5,319-25.

21. Bouhuys A, Heaphy LJ Jr, Schilling RSF. Byssinosis in the United States. N Engl J Med 1967;277:170-4.

22. Parikh JH. Byssinosis in developing countries. Br J Ind Med 1992;49:217-9.

23. Schilling RSF, Vigliani EC, Lammers B, Valic F, Gilson JC. A report on a conference on byssinosis. International Congress Series No 62. New York: Excerta Medica Foundation, 1963:137-45.

24. Imbus HR. Cotton dust. Am Ind Hyg Assoc J 1986;47:712-6.

25. Lee WR. Clinical diagnosis of byssinosis. Thorax 1979:34:287-9.

26. Weill H. Problem solving in occupational airway disorders. Chest 1979;79(Suppl);4:1-2.

27. Morgan WKC, Vesterlund J, Burrell R, Gee JBL, Willoughby WF. Byssinosis: Some unanswered questions. Am Rev Respir Dis 1982;126:354-7.

28. Beck GJ, Schacter EN, Maunder LR. The relationship of respiratory symptoms and lung function loss in cotton textile workers. Am Rev Respir Dis 1984;130:6-11.

29. Occupational Safety and Health Administration. Occupational exposure to cotton dust. Fed Regist 1985;50:51120-79.

30. Iverson M, Dahl R, Jensen EJ, Korsgaard J, Hallas T. Lung function and bronchial reactivity in farmers. Thorax 1989;44:656-9.

31. Rijcken B, Schouten JP, Weiss ST, Meinesz AF, DeVries K, VanDerLende R. The distribution of bronchial responsiveness to histamine in symptomatic and asymptomatic subjects. Am Rev Respir Dis 1989;140:615-23.

32. Ostiguy G, Vaillancourt C, Bégin R. Respiratory health of workers exposed to metal dusts and foundry fumes in a copper refinery. Occup Environ Med 1995;52:204-10.

33. Kueppers F, Miller RD, Gordon H, Hepper NG, Offord K. Familial prevalence of chronic obstructive pulmonary disease in a matched pair study. Am J Med 1977;63:336-42.

34. Martin RR, Durant P, Ghezzo H. Studies on the health of primary aluminium workers in Quebec: Airway obstruction-chronic components. Montréal: Alcan Aluminium, 1986.

35. Miller A, Warshaw R, Thornton JC. Prevalence of spirometric abnormalities in a representative sample of the population of Michigan. Am J Ind Med 1991;19:473-85. 


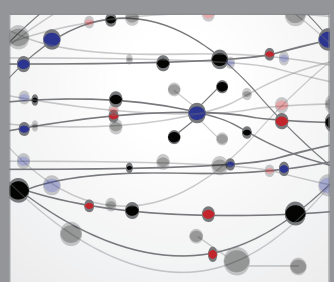

The Scientific World Journal
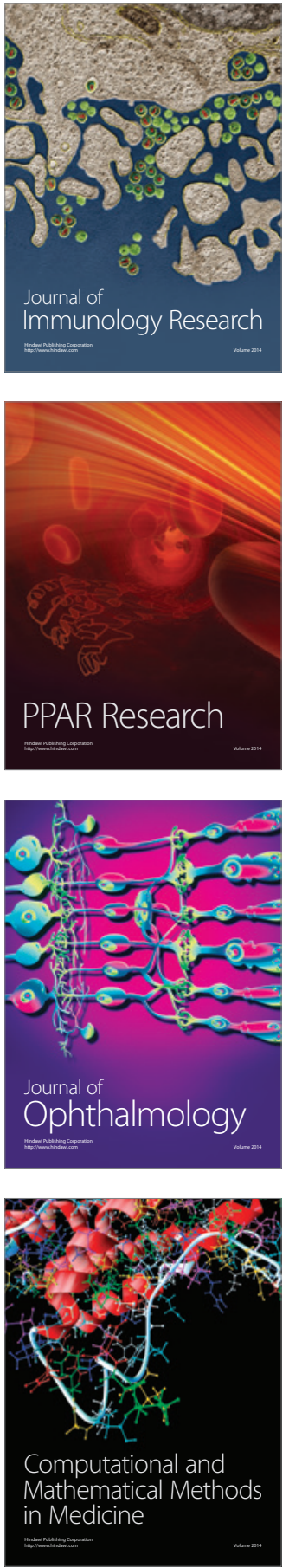

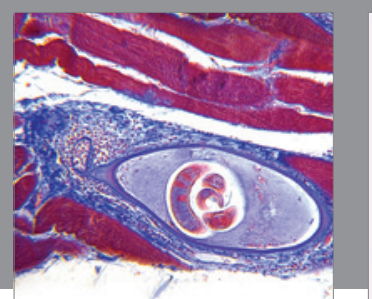

Gastroenterology Research and Practice

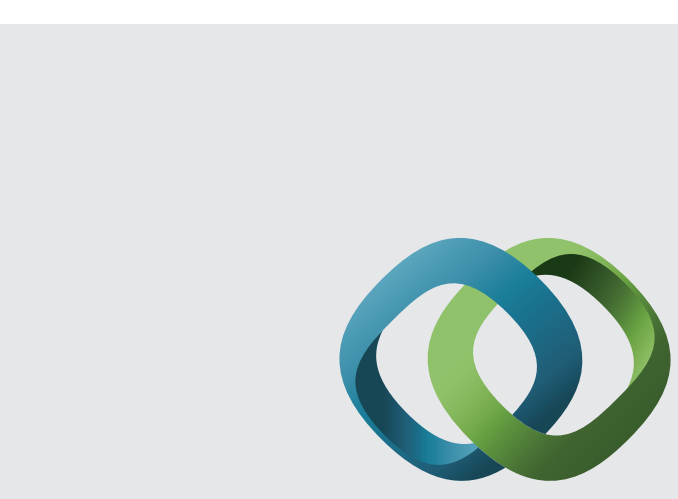

\section{Hindawi}

Submit your manuscripts at

http://www.hindawi.com
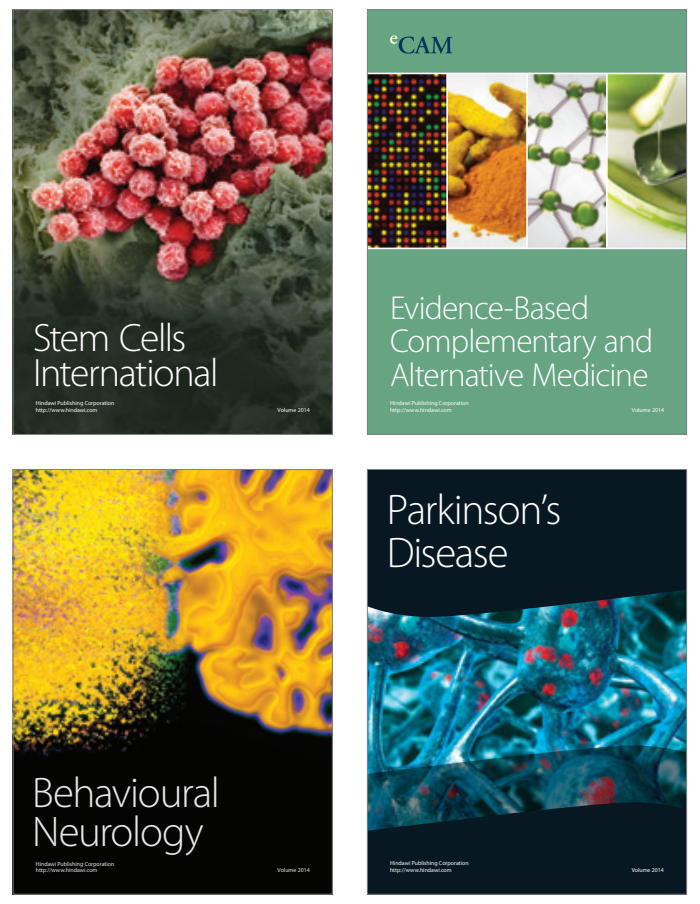
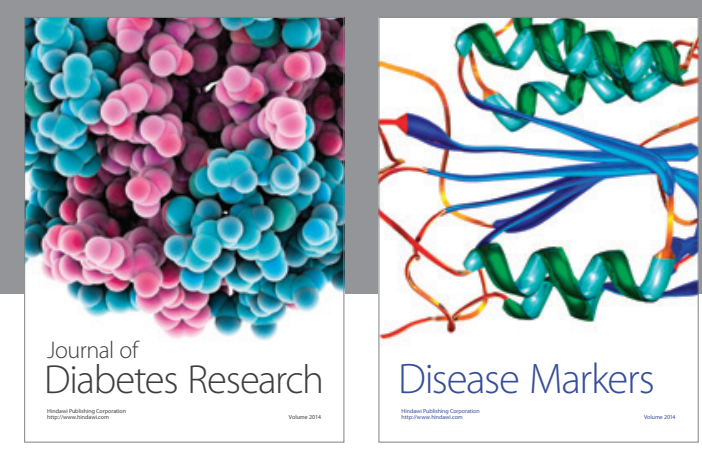

Disease Markers
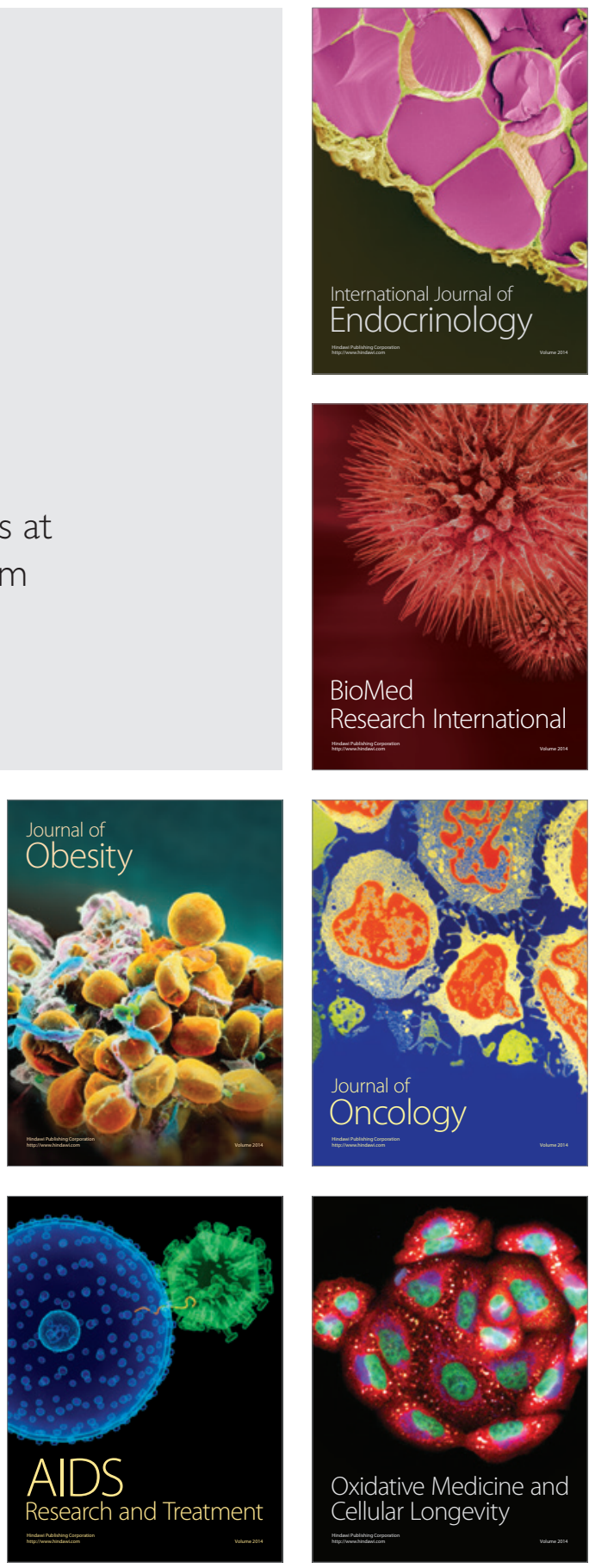